American University Washington College of Law

Digital Commons @ American University Washington College of

Law

Articles in Law Reviews \& Other Academic Journals

Scholarship \& Research

2017

Blood Antiquities: Addressing a Culture of Impunity in the Antiquities Market

Paul Williams

Christin Coster

Follow this and additional works at: https://digitalcommons.wcl.american.edu/facsch_lawrev

Part of the Criminal Law Commons, Cultural Heritage Law Commons, International Law Commons, Legal History Commons, and the Military, War, and Peace Commons 


\title{
Blood Antiquities: Addressing a Culture of Impunity in The ANTIQUities MARKET
}

\author{
Paul R. Williams* \& Christin Coster ${ }^{\dagger}$
}

For decades, parties to conflicts have used the cover of war to destroy and loot cultural property and antiquities for financial gain and symbolic victory. The "blood antiquities" excavated in conflict areas and sold mostly in western markets fuel not only continued conflict, but also (as in cases such as Syria and Iraq) terrorism that can reach around the world. The culture of impunity for both buyers and sellers of antiquities allows the blood-antiquities trade to thrive.

A robust international legal framework does exist to ensure accountability for the destruction of cultural heritage. Because looting is a major cause of destruction, it should be included in this framework. The successful prosecution of Ahmad Al Faqi Al Mahdi by the International Criminal Court (ICC) on charges of deliberately attacking historical and cultural monuments bodes well for an end to impunity. Yet, this paper argues that international and domestic systems of regulation and certification are also needed to establish criminal liability and eliminate the willful ignorance of buyers.

Rebecca Grazier Professor of Law and International Relations, American University. Ph.D., Cambridge University, 1998; J.D., Stanford Law School, 1990; B.A., U.C. Davis 1987. From 1991 to 1993, Professor Williams served as an Attorney-Advisor in the United States Department of State's Office of the Legal Advisor for European Affairs. In 1995, he founded the Public International Law \& Policy Group (PILPG), which provides pro bono public international legal assistance to states and substate entities. In the course of his career, Dr. Williams has assisted over two dozen states in major international peace negotiations and has advised numerous governments on the drafting and implementation of post-conflict constitutions. Several of Dr. Williams' pro bono government clients throughout the world joined together to nominate him for the Nobel Peace Prize in thanks for his assistance. Dr. Williams would like to thank Alexandra Brown for her help in preparing this article.

$\dagger \quad$ M.S.D.M., School of International Service, American University, 2016; Program Associate, Public International Law \& Policy Group, Washington, D.C.; Returned Peace Corps Volunteer, Namibia, 2013; B.A., International Relations, Wheaton College, 2009. 


\section{CONTENTS}

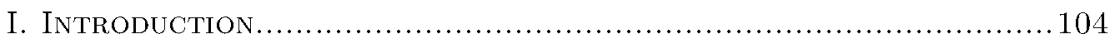

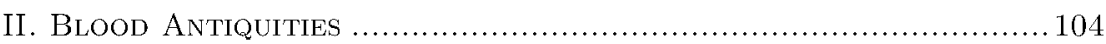

III. Culture of Impunity ............................................... 108

IV. International Legal Frameworks to Protect Cultural

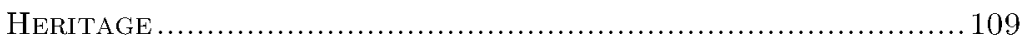

V. Reliance on Domestic Legal Frameworks.............................. 112

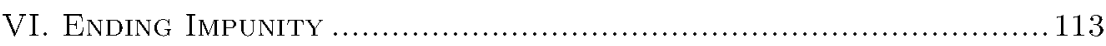

\section{INTRODUCTION}

On August 22, Ahmad Al Faqi Al Mahdi pled guilty at the International Criminal Court (ICC) on charges of deliberately attacking historical and cultural monuments - the first ever prosecution for the destruction of cultural heritage in front of the ICC. ${ }^{1}$ In the summer of 2012, Al Mahdi led a task force of Ansar Dine jihadists to destroy historic tombs in Timbuktu, Mali, which had attracted African and Middle Eastern Muslim pilgrims for centuries. ${ }^{2}$ The Muslim extremists occupied Timbuktu for nearly a year before French forces finally ousted them. ${ }^{3}$ The case against Al Mahdi provides some hope that more perpetrators will be brought to justice for destroying cultural property and antiquities, including the members of ISIS who have left a trail of ruin across Iraq and Syria. ISIS, however, not only destroys cultural sites, but also loots them and exploits the antiquities trade to raise substantial funds to sponsor its operations. ${ }^{4}$ The lack of accountability for looting and purchasing illegal antiquities allows terrorism and conflict to flourish in the Middle East.

\section{Blood Antiquities}

Just as "blood diamonds" helped to fund devastating conflict in Western, Central, and Southern Africa, "blood antiquities" are

1. Melik Kaylan, A Landmark Precedent to Protect Cultural Heritage, WALL ST. J. (Aug. 30, 2016), http://www.wsj.com/articles/a-landmarkprecedent-to-protect-cultural-heritage- 1472590560 [https://perma.cc/RE9B-APNS].

2. Id.

3. Id.

4. Pamela Engel, ISIS's looting of the Middle East is 'the largest-scale mass destruction of cultural heritage since' WWII, Bus. INSIDER (Jan. 12, 2016, 2:10 PM), http://www.businessinsider.com/isis-antiquities-destroyedsmuggling-2016-1[https:/perma.cc/3KUC-D7WT]. 
financing terrorism and conflict in the Middle East. ${ }^{5}$ Although ISIS claims to destroy some sites purely out of religious zeal, attempting to erase all signs of what they call idolatry, ${ }^{6}$ ISIS and the Syrian regime have both been accused of looting cultural heritage sites like Palmyra for profit. ${ }^{7}$ Although the precise profits that ISIS generates from looting are difficult to calculate, estimates range from $\$ 200$ million to $\$ 8$ billion. ${ }^{8}$ The Wall Street Journal emphasized the importance of this income stream when it reported that looted antiquities are ISIS's second-largest source of financing after oil. ${ }^{9}$

Syrians on the ground report that ISIS issues licenses to loot in exchange for a $20-50$ percent tax on the proceeds. ${ }^{10}$ Indeed, a U.S.-led raid on the compound of ISIS's oil-smuggling and antiquities-trade commander provided evidence of this practice. ${ }^{11}$ The commander possessed an assortment of artifacts and receipts showing a 20-percent tax on precious materials, including antiquities and minerals collected from civilians. ${ }^{12}$

5. Mark V. Vlasic, Islamic State Sells 'Blood Antiquities' from Iraq and Syria to Raise Money, WAsh. POST (Sept. 14, 2014), https:/ www. washingtonpost.com/opinions/islamic-state-sells-bloodantiquities-from-iraq-and-syria-to-raise-money/2014/09/14/49663c983a7e-11e4-9c9f-ebb47272e40e_story.html?utm_term=.dba16931c5ed [https://perma.cc/SQE7-7KKQ].

6. Eric Gibson, The Destruction of Cultural Heritage Should be a War Crime, WALL ST. J. (March 2, 2015, 12:38 PM), http://www.wsj.com/articles/the-destruction-of-cultural-heritageshould-be-a-war-crime-1425073230 [https://perma.cc/BTY3-2BX6]; Kareem Shaheen, Isis Fighters Destroy Ancient Artefacts at Mosul Museum, GUARDIAN (Feb. 26, $2015 \quad 4: 26 \quad$ PM), https://www. theguardian.com/world/2015/feb/26/isis-fighters-destroyancient- artefacts-mosul- museum-iraq [https://perma.cc/E6P4-J2Z8].

7. Syrian Troops Looting Ancient City Palmyra, Says Archaeologist, GUARDIAN (June $1, \quad 2016, \quad 3: 17 \quad$ PM), https://www.theguardian.com/world/2016/jun/01/syrian-troops-lootingancient-city-palmyra-says-archaeologist [https://perma.cc/NY5A-TB2J].

8. Georgina Adams, Antiquities: The Spoils of War, Fin. TIMES (March 11, 2016), http://www.ft.com/cms/s/0/950b8740-e1f6-11e5-92176ae3733a2cd1.html\#axzz4JnFjtNbK [https://perma.cc/V2QG-AXY8].

9. Mark V. Vlasic \& Helga Turku, Countering IS's Theft and Destruction of Mesopotamia, WORLD POL'Y BLOG (July 7, 2015, 8:55 AM), http://www.worldpolicy.org/blog/2015/07/07/countering-is's-theft-anddestruction-mesopotamia [https://perma.cc/6BDE-NLYV].

10. Id.

11. Celestine Bohlen, Escalating the War on Looting, N.Y. TIMES (March 11, 2016), /2016/03/12/arts/international/escalating-the-war-onlooting.html?_r=0 [https://perma.cc/W9FL-EHCU].

12. Id. 
Evidence suggests that thieves are storing many looted antiquities in warehouses for a cooling-off period, after which they will be more difficult to trace. ${ }^{13}$ In March 2015, a police raid in Bulgaria uncovered a stash of items thought to be from the Sumerian city of Lagash, in Southern Iraq. ${ }^{14}$

According to experts, traffickers and middlemen use a vast network of smuggling channels, many through Lebanon or Turkey, to move the antiquities from their country of origin to international markets. ${ }^{15}$ Once antiquities leave their country of origin, it is often difficult to prove that they were looted from a conflict area rather than transferred through legitimate channels. ${ }^{16}$ Smugglers' frequent use of forged documents exacerbates the problem further. ${ }^{17}$ According to news reports, the lack of concrete evidence of illegal excavation often compels authorities to avoid pursuing criminal charges against smugglers in return for reclaiming the stolen objects, thereby allowing the perpetrators to escape liability. ${ }^{18}$

Reports indicate that many looted antiquities end up with buyers in Western markets and the Gulf. ${ }^{19}$ According to Lynda Albertson, $\mathrm{CEO}$ of the Association for Research into Crimes against Art in Rome, lawmakers have not paid enough attention to preventing buyers in wealthy markets from purchasing looted antiquities. ${ }^{20}$

Today, front-page news often features ISIS and the Middle East, but antiquities trafficking is hardly novel, having funded terrorism for decades. For example, in 1999, one of the hijackers from the 9/11 attacks sold ceramics in Germany, which were stolen from Afghanistan, allegedly with the intent of purchasing an airplane. ${ }^{21}$ In addition, during

13. Bill Briggs, How Terrorists Tap a Black Market Fueled by Stolen Antiquities, NBC NEws (June 23, 2014), http://www.nbcnews.com/storyline/iraq-turmoil/how-terrorists-tapblack-market-fueled-stolen-antiquities-n137016 [https://perma.cc/X9ZTZQVV].

14. Bohlen, supra note 11.

15. Joe Parkinson \& Duncan Mavin, West Seeks Tighter Curbs on Trade in Antiquities Looted by Islamic State, WALL ST. J. (March 30, 2015), http://www.wsj.com/articles/west-seeks-tighter-curbs-on-trade-inlooted-antiquities-1427761561 [https://perma.cc/C4GP-DH8W].

16. Id.

17. Briggs, supra note 13.

18. Bohlen, supra note 11.

19. Parkinson \& Mavin, supra note 15.

20. Parkinson \& Mavin, supra note 15.

21. Heather Pringle, New Evidence Ties Illegal Antiquities Trade to Terrorism, Violent Crime, NAT'L GEOGRAPHIC (June 13, 2014), http://news.nationalgeographic.com/news/2014/06/140613-looting- 
the Cambodian Civil War in 1970, the Vietnam People's Army and the Khmer Republic instituted industrial looting. ${ }^{22}$ Similarly, after the Russian Civil War and the famine-induced peasant uprisings in 1922, the Soviet regime looted property from the Russian Orthodox Church, Armenian Orthodox Church, Greek Orthodox Church, and Anglican Church of Moscow, as well as Jewish synagogues. ${ }^{23}$ That year, thousands of stolen antiquities were sold to foreign collectors, which raised billions of dollars, primarily for arms purchases from Germany. ${ }^{24}$

While terrorists gain financially from looting, the people who view these artifacts as part of their cultural heritage experience an emotional and financial cost from the theft. Ancient sites and monuments often represent not only symbols of national unity and pride, ${ }^{25}$ but also important religious or cultural heritage. Cultural heritage is a valuable part of individual and group identity, ${ }^{26}$ which is one reason why terrorists choose to target it. ${ }^{27}$ Destruction of cultural sites can lead to anger, division, and retaliation that fuel further conflict. ${ }^{28}$ In addition, countries often gain significant revenue from tourism at cultural heritage sites, which is greatly reduced during conflict or instability. ${ }^{29}$ The ancient site of Palmyra, for example, received 150,000 tourists a

antiquities-archaeology-cambodia-trafficking-culture/ [https://perma.cc/LHM5-J7QL].

22. Samuel Andrew Hardy, The Conflict Antiquities Trade: A Historical OVERVIEW, 27 (2015).

23. Id.

24. Id.

25. Amr Al-Azm, Why ISIS Wants to Destroy Syria's Cultural Heritage, Time (Oct. 8, 2015), http://time.com/4065290/syria-cultural-heritage/ [https://perma.cc/3KDU-JHKX].

26. Stephen Stenning. Destroying Cultural Heritage: More Than Just Material Damage, BRIT. CouncIL (Aug. 21, 2015, 10:14 AM), https://www.britishcouncil.org/voices-magazine/destroying-culturalheritage-more-just-material-damage https://perma.cc/JTF5-SDPS].

27. Dana Ballout, U.N. Condemns Destruction of Ancient Palmyra Temple, $\begin{array}{llllll}\text { WALL ST. J. } & \text { (Sep. 1, 2015, } & \text { 9:26 } & \text { PM), }\end{array}$ http://www.wsj.com/articles/ancient-palmyra-temple-completelydestroyed-u-n-says-1441116972 [https://perma.cc/4QW6-H37Q].

28. David W. Bowker, Laura Goodall \& Rebecca A. Haciski, Confronting ISIS's War on Cultural Property, 20 AM. SOC'Y INT'L L. INSIGHTS 12 (July 14 , $2016)$ https://www.asil.org/insights/volume/20/issue/12/confronting-isis-warcultural-property [https://perma.cc/4W6A-W5QM].

29. Deborah Lehr, Digging out of Tourism Downfalls: Egypt's Archaeology Takes the Stage, Huffington Post (Feb. 16, 2015, 12:50 PM), http://www.huffingtonpost.com/deborah-lehr/digging-out-of-tourismdo_b_6341104.html [https://perma.cc/T3RN-M5XP]. 
year before Syria's civil war began. ${ }^{30}$ This income stream cannot be recovered if ISIS completes its destruction of the site.

It seems surprising that ISIS, a terrorist organization that the U.N. has condemned for destroying cultural sites, ${ }^{31}$ has managed to infiltrate the international antiquities market and sell antiquities to high-end collectors without consequence. Unfortunately, the culture of impunity for purchasers and the weak regulatory system make this scenario possible.

\section{Culture OF Impunity}

There is technically nothing illegal about owning and purchasing antiquities; the legality of the trade revolves around how the antiquities have been acquired. ${ }^{32}$ Many antiquities are considered legal even though their provenance is ambiguous because they have been in circulation so long. ${ }^{33}$ For example, the antiquities removed during periods of colonial rule were made legal simply through the passage of time. ${ }^{34}$

Surprisingly, laws facilitate the transformation of illicit antiquities to licit ones. ${ }^{35}$ The majority of antiquities on the market are sold with no provenance documentation, which is a strong indication that they were looted from archaeological sites, museums, churches, or private collections. ${ }^{36}$ Legal conceptualizations of property and ownership, however, can turn these illicit antiquities into legal ones through protections for good faith purchasers. ${ }^{37}$ Many civil-law countries maintain that if someone purchases an antiquity in good faith, the purchaser has good title and the object is no longer considered a stolen good. ${ }^{38}$ Other legal doctrines that facilitate the process of creating good title are statutes of limitations, allocation of the burden of proof, and adverse possession. ${ }^{39}$

30. Palmyra's Temple of Bel Destroyed, Says U.N., BBC (Sep. 1, 2015), http://www.bbc.com/news/world-middle-east-34111092 [https://perma.cc/AYN8-ZPCP].

31. Ballout, supra note 27.

32. Blythe A. Bowman, Transnational Crimes Against Culture, $24 \mathrm{~J}$. Contemp. Crim. Just. 3, 227 (Aug. 2008).

33. Id. at 22728 .

34. Id.

35. Id.

36. Id.

37. Id. at 233 (defining "good faith purchaser" as someone who purchases antiquities with no knowledge that they were illegally looted).

38. Id.

39. Id. 
While some purchases of illegal antiquities are honest mistakes, others result from willful ignorance. ${ }^{40}$ For instance, in 2002, Sotheby's auction house sold $\$ 3$ million worth of Egyptian antiquities. ${ }^{41}$ By 2010 , the amount of looting in Egypt doubled as a result of the global recession, while at the same time Sotheby's sales figures for Egyptian antiquities rose to $\$ 13$ million for the year. ${ }^{42}$ Given the strong likelihood that Egyptian antiquities entering the market during this period were illicitly acquired, "good faith" purchases of these items seem almost impossible. ${ }^{43}$

The culture of impunity contributes to the intrinsically linked challenges of preventing the illegal trafficking and sale of blood antiquities and establishing accountability for looters and buyers.

\section{International Legal Frameworks to Protect Cultural Heritage}

Although only a very weak regulatory system exists to prosecute the looting and purchase of conflict antiquities, there is a strong international legal framework that has succeeded in holding individuals accountable for the destruction of cultural heritage. Because looting, as demonstrated by ISIS, necessarily involves the destruction of cultural sites, it belongs within this legal framework.

The first pillar in the framework is the 1954 Hague Convention for the Protection of Cultural Property in the Event of Armed Conflict, which was adopted as a result of the severe cultural destruction that occurred during World War II. The Convention covers immovable and moveable cultural heritage, including monuments, art, archaeological sites, scientific collections, manuscripts, books, and other objects of artistic, historical, or archaeological interest. ${ }^{44}$ The Convention prohibits parties to an armed conflict from exercising "direct hostilities

40. Sarah Parcak, Lust for Loot: Collecting Is Driving the Demand for Plunder, NAT'L Geographic: EXPLORERS J. (May 19, 2016), http://voices.nationalgeographic.com/2016/05/19/lust-for-lootcollecting-antiquities-looting-egypt/ [https://perma.cc/P9U4-88GW].

41. Id.

42. Id.

43. See Sarah Parcak, David Gathings, Chase Childs, Greg Mumford \& Eric Cline, Satellite Evidence of Archaeological Site Looting in Egypt: 2002 2013, 90 ANTIQUiTy 349, 188, 189 (2016) (noting that two-thirds of Egyptian antiquities sold at Sotheby's in the last decade lack provenance prior to 1973).

44. Convention for the Protection of Cultural Property in the Event of Armed Conflict art. 1, Mar. 13, 2009, 249 U.N.T.S. 240. 
against cultural property," and requires them to "avoid incidental damage to such property." 45

The second pillar is the 1977 Protocol II amendment to the Geneva Conventions, which applies to non-international armed conflicts. The Protocol prohibits "any acts of hostility directed against historic monuments, works of art or places of worship which constitute the cultural or spiritual heritage of peoples, and [using] them in support of the military effort." ${ }^{46}$ By including protections for cultural objects, the Protocol highlights the importance of safeguarding humankind's heritage. ${ }^{47}$

The third pillar is the Rome Statute of the ICC, which designates as a war crime the intentional attack against "buildings dedicated to religion, education, art, science or charitable purposes, historic monuments, hospitals and places where the sick and wounded are collected, provided they are not military objectives."48 The International Criminal Tribunal for the Former Yugoslavia (ICTY), for instance, applied the Rome Statute when it convicted Pavle Strugar ${ }^{49}$ and Jadranko Prlićs ${ }^{50}$ of destroying cultural property along with other war crimes, such as murder and civilian attacks.

Recently, the ICC conducted its first war-crimes trial based solely on the charge of cultural-monument destruction. Ahmad Al Faqi Al Mahdi, a member of the Islamist extremist group Ansar Dine, was accused of, and plead guilty to, ${ }^{51}$ destroying the Sidi Yahia Mosque and nine mausoleums in Timbuktu, Mali. ${ }^{52}$ The proceedings against $\mathrm{Al}$

45. Protection of Cultural Property in the Event of Armed Conflict, INT'L Comm. Red Cross (Oct. 29, 2010), https://www.icrc.org/eng/war-andlaw/conduct-hostilities/cultural-property/overview-culturalproperty.htm [https://perma.cc/U6NN-LDVE].

46. Protocols Additional to the Geneva Conventions of 12 August 1949 art. 16 , available

https://www.icrc.org/eng/assets/files/other/icrc_002_0321.pdf [https://perma.cc/SUP2-GFDB].

47. See id.

48. Rome Statute of the International Criminal Court art. 8, signed but not ratified Dec. 31, 2000, 37 I.LM. 999.

49. Judgement in the Case the Prosecutor v. Pavle Strugar: Pavle Strugar Sentenced to Eight Years' Imprisonment, INT'L. CRIM. TRIB. FOR THE FORMER YUgOSLAVIA (Jan. 31, 2005), http://www.icty.org/en/press/judgement-case-prosecutor-v-pavlestrugar-pavle-strugar-sentenced-eight-years\%E2\%80\%99-imprisonment 1/ [https://perma.cc/2TPG-ERL5].

50. Prosecutor v. Prlić, Case No. IT-04-74-T, Judgement Summary, \ 4 (Int'l Crim. Trib. for the Former Yugoslavia May 29, 2013).

51. Kaylan, supra note 1.

52. Malian Jihadi to Plead Guilty in ICC Cultural Destruction Trial, GUARDIAN (May 24, 2016, 8:15 AM), 
Mahdi are pivotal because a war-crimes conviction would not only demonstrate the serious nature of cultural-property destruction, but also encourage compliance with the laws protecting cultural heritage..$^{53}$

The fourth pillar consists of post-conflict peace agreements that intentionally address the issue of cultural destruction. Annex 8 of the Dayton Accords, which ended the conflict in the former Yugoslavia, is formally titled the Agreement on Commission to Preserve National Monuments. ${ }^{54}$ Annex 8 guarantees the citizens of Bosnia and Herzegovina the right to protect, reconstruct, and rehabilitate cultural property. ${ }^{55}$ After the Yugoslav Wars, the national government of Bosnia and Herzegovina adopted legislation that implemented Annex 8 and facilitated cultural monument reconstruction, such as by easing the process for obtaining construction permits. ${ }^{56}$ Rebuilding was a necessary part of the process allowing citizens to regain their dignity and identity. ${ }^{57}$

The fifth pillar is the UNESCO Convention on the Means of Prohibiting the Illicit Import, Export, and Transfer of Ownership of Cultural Property (UNESCO Convention), which provides the right to repatriate stolen or illegally exported antiquities from other member countries. The convention, however, limits recovery to "property stolen from a museum or a religious or secular public monument or similar institutions provided that such property is documented as appertaining to the inventory of that institution." "58 Importantly, the UNESCO Convention does not explicitly cover unprovenanced antiquities.

Although this international framework, in particular the ICC conviction of Al Mahdi, provides some hope that future prosecutions against ISIS members for cultural-heritage destruction will ensue, it

https://www.theguardian.com/law/2016/may/24/malian-jihadi-toplead-guilty-forgiveness-icc-cultural-destruction-trial [https://perma.cc/3N7N-FKRQ].

53. Marina Lostal, ICC Opens a Case for the Destruction of Cultural Heritage in Mali, GLOBAL POL'Y FORUM (Oct. 2, 2015), https://www.globalpolicy.org/home/163-general/52814-icc-opens-a-casefor-the-destruction-of-cultural-heritage-in-mali.html [https://perma.cc/C35F-QNU2].

54. Valery Perry, Reversing Ethnic and Cultural Cleansing: The Role of Annex 8 in Reclaiming History, Promoting Post-War Reconciliation and Preserving the Unique Cultural Heritage of Bosnia and Herzegovina, 2 EUR. Y.B. MINORITY ISSUES 197, 198 (2002/3).

55. Id.

56. Id. at 211-14.

57. Id. at 22324 .

58. Convention on the Means of Prohibiting and Preventing the Illicit Import, Export and Transfer of Ownership of Cultural Property art. 7, Sept. 2, 1983, 10 I.L.M. 289. 
does nothing to caution smugglers and buyers of illegal antiquities. Given that the purchase of blood antiquities plays a large role in financing conflict and terror, it is a mistake for international law to focus only on the supply side.

\section{Reliance on Domestic Legal Frameworks}

Absent an international legal framework for criminal liability, the only currently available means to hold individuals accountable for trade in looted antiquities is through the domestic courts.

In the U.S., relevant national legislation includes the Convention on Cultural Property Implementation Act of 1983 (CCPIA), which gave effect to sections of the UNESCO Convention and the National Stolen Property Act (NSPA). ${ }^{59}$ The NSPA criminalizes the transportation, sale, and receipt of illegally obtained goods by individuals with knowledge of the goods' illegal status. ${ }^{60}$ Although defendants have been successfully prosecuted under this law ${ }^{61}$ prosecutors face difficulties in demonstrating both the "illegally-obtained" and "with knowledge" elements of the crime.

With respect to the first element, it is difficult to prove that antiquities are stolen, especially unprovenanced antiquities. Under U.S. law, the proof requires two steps: (1) there must be a foreign-nation vesting statute, often called a patrimony law, which establishes ownership by the state; and (2) there must be evidence of illegal export which constitutes the theft. ${ }^{62}$ Because of the often-ambiguous circumstances surrounding the excavation and ownership history of a cultural antiquity, however, evidence gathering can be a significant barrier to prosecution. ${ }^{63}$

With regard to the second element, proving that a defendant knew an object was illegally excavated is challenging "[o]nce antiquities are removed from their context." hundreds of years ago and have been traded with little or no

59. Stephen K. Urice, Between Rocks and Hard Places: Unprovenanced Antiquities and the National Stolen Property Act, 40 N.M. L. REV. 123, 126-27(2010).

60. 18 U.S.C.A. $\$ 2314$ (2013).

61. Id.

62. Urice, supra note 59, at 130.

63. Summary of Law: National Stolen Property Act, NAT'L OCEANIC \& Atmospheric Admin. Office for Coastal Mgmt (last visited Oct. 16, 2016), https://coast.noaa.gov/data/Documents/ OceanLawSearch/Summary\%20of\%20Law\%20\%20National\%20Stolen\%20Property\%20Act.pdf?redirect=301ocm [https://perma.cc/V57Y-DG7W].

64. Id. 
recordkeeping, making it difficult for collectors to know the legality and provenance of the items for sale. ${ }^{65}$ The legal protections for "good faith" buyers and the culture of willful ignorance adds further complication.

\section{ENDING IMPUNITY}

Some govermments are taking steps to strengthen domestic systems of accountability. American, British, and German authorities are creating legislation to make it easier to prosecute defendants accused of antiquities theft. Western intelligence agencies have also formed a task force to monitor trade in antiquities. ${ }^{66}$ Furthermore, UNESCO is using $\$ 3.5$ million in E.U. funds to train customs officials to detect antiquities before they reach buyers. ${ }^{67}$

New legislation to combat the looted-antiquities trade centers on using stronger import controls to prevent the artifacts from reaching buyers. ${ }^{68}$ This approach resembles the efforts to combat conflict diamonds, which focused on certifying stones not mined in conflict zones before they reach legal markets. This certification procedure resulted from what is known as the Kimberly Process, ${ }^{69}$ which began when Southern African diamond-producing states met to discuss ways to prevent the diamond trade from financing violence in the region. ${ }^{70}$ In 2000, the United Nations General Assembly (UNGA) adopted a resolution supporting an international certification plan for conflict-free diamonds. ${ }^{71}$ Resulting from negotiations between governments, nongovernmental organizations, and diamond-industry members, the Kimberley certification scheme has been adopted by 81 countries and covers 99.8 percent of the global diamond production. ${ }^{72}$ While this system is not without critics, it illustrates the capacity of the international community to regulate trade in conflict-related goods. ${ }^{73}$

65. Id.

66. Parkinson \& Mavin, supra note 15.

67. Id.

68. Id.

69. Kimberley Diamonds Process Certification, U.S. Customs \& BordeR Protection (Aug. 5, 2016), https://www.cbp.gov/trade/programsadministration/kimberley-diamonds-process-certification [https://perma.cc/3WAH-L4JD].

70. About: KP Basics, KimBerLey Process (last visited Oct. 16, 2016), https://www.kimberleyprocess.com/en/about [https://perma.cc/L665L36P].

71. Id.

72. Id.

73. See David Rhode, The Kimberley Process is a 'Perfect Cover Story' for Blood Diamonds, GuardiaN (Mar. 24, 2014, 10:40 AM), https://www.theguardian.com /sustainable-business/diamonds-blood- 
The discrepancy between global efforts to prevent the sale of "blood diamonds" and "blood antiquities" highlights the relative weakness of the regulatory oversight of the trade in antiquities.

However, even a regulatory system that could adequately certify that antiquities are "conflict free" would fail to hold the demand side of the trade accountable for its role in illicit looting and dealing. The regulations would not address the culture of impunity that accompanies the willful ignorance of collectors.

One proposed solution would be the creation of a global registry of legitimate antiquities through collaboration between the collecting and scholarly communities. ${ }^{74}$ Then, international and national legal regimes could be created to criminalize the sale or purchase of any antiquity not on the registry. ${ }^{75}$ Countries could also develop a system for certifying legitimate antiquities dealers and making purchases from non-certified dealers illegal. Additionally, buyers purchasing antiquities known to be from areas where terror groups operate could be prosecuted for financing terrorism. ${ }^{76}$

Without a system of accountability, terrorist groups such as ISIS will continue to profit from looting and use their financial gains to take more lives in the Middle East and the West. It is therefore of the utmost importance to establish regulations and legislation as suggested above to interrupt both the demand and supply sides in the market for blood antiquities.

kimberley-process-mines-ethical [https://perma.cc/FXJ8-RRUH] (discussing the pros and cons of the Kimberley Process while future endeavors to deal with "blood diamonds.").

74. Tom Mueller, How Tomb Raiders are Stealing our History, NAT'L GEOGRAPHIC (Jun. 2016), http://www.nationalgeographic.com/magazine/2016/06/looting-ancientblood-antiquities/ [https://perma.cc/FVL3-3HAR].

75. Id.

76. Buyers of Looted Artifacts may be Charged with Aiding ISIS FBI, RT: AMERICA (Aug. 27, 2015, 10:22 PM), https://www.rt.com/usa/313654fbi-isis-looted-artifacts/ [https://perma.cc/JHE4-XYZF]. 